\title{
紅茶の炭水化物について
}

静岡犬学晨学部農荎化学科 水 野 卓 - 金 兵 忠 雄

\section{Studies on the Carbohydrates of Black Tea}

\author{
By 'Takashi Mızuno and Tadao KInPyō
}

茶 (茶生葉, 㹕茶飞ついて)の成分中，力テキン・有 機塩基・アミノ酸・香気・色素類及び酵素類などについ ては数多くの詳しい研究成果が見られるが，ひとり茶の 炭水化物類については量的飞も多く主要成分の一つであ

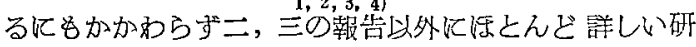
究任見られみい。

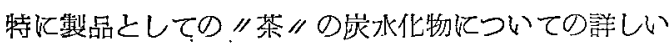

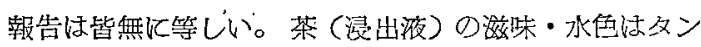
ニン・アミノ酸・カフェイン・色素などに大きく左右さ

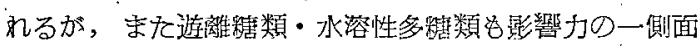
をなしているものと思われる。

著者等は値物としての茶及び製品としての茶の掞水化 物について総合的な研究の緒につき，その一つとして紅 茶の宸水化物の種類を一通り検案したので赫告する。

発表に当り，試料について 御便宜と当骨折りをいただ

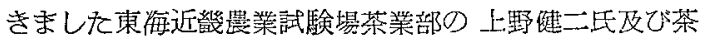
業部製茶第二研究室の方々に併子て樑甚の謝意を表し，

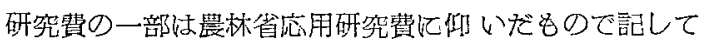
感謝する。

\section{1. 供 試 料}

静岡県磐田郡山香地方の代表茶園から，1954年 8 月18 日摘葉した茶葉(在来種) 加ら常法に佂つて製造した紅 茶 (審查総評点 $95.1 / 120$ で立品) を粉砕機で砕湓し，1 $\mathrm{mm}$ 目の篩定全部通して供試料とした。

\section{2. 紅茶の一般化学組成}

常法に従つて分析した結果は第 1 表のようである。

すなわち紅茶の化学成分中, 無水物当り73\%が宸水化 物類で量的江は最も多い，乙の中可溶性炭水化物が $61 \%$ ， 粗纎維が $12 \%$ で，ペクチン $12 \%$ ，ペントーザン $6 \%$ も含 まれている。次いで粗㶾白誓18\%であるが，乙の内には アミノ酸態滘素などを含をので，真正蛋白質はかなり少 いものと考えられる。

この他タンニン $9 \%$, 粗灭分 $6 \%$, 粗脂肪 $3 \%$, 可 溶性室素1.5\%を含み，ての中 $1.1 \%$ がカフェイン態で他 がアミノ酸アミド態窒素ねと゚と考えられる。ね的エーデ ル抽出液が濃緑色で赤色の算光を発するととからして，
粗脂肪中にはかなりの量のクロロフィールを 包含するも のと考えられる。

第 1 表 紅茶の一般化学成分（䍢水物\%)

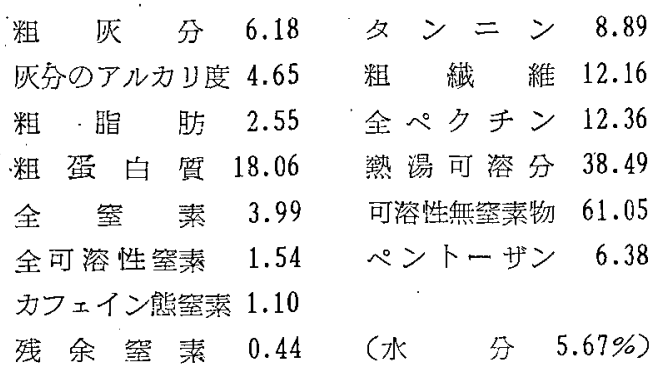

\section{3. 紅茶の炭水化物の分別檢索法}

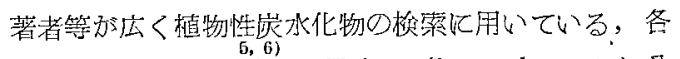
溶剤炕よる段階的分別法飞準じて各フラクションに分

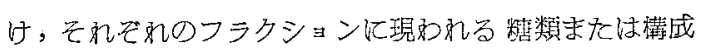

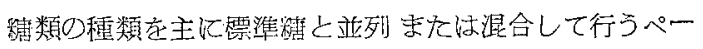
パークロマトグラフによつて模甞同定した。

\section{4. 紅茶の炭水化物の種類}

紅茶の炭水化物の段階的分别检罙結果をまどあて示せ

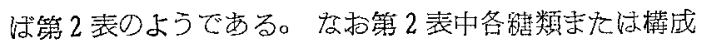
䄼の種類は，ペーパークロマトグラム上飞現われるスポ ットの著明な順纪記载した。

\section{5. 総括}

段跸的分別法によつて 紅茶の炭水化物孛 14 フラクショ

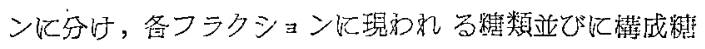

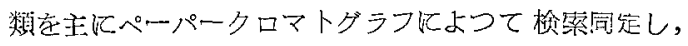
次の結果を得市 (䈐 2 表参照)。

1. 游離単瞊類としてはフラクトース，グルコース， アラビノースを，遊離オリゴ䌅類としてはシェクロース， マルトース，ラフィノース，スタ伢ース検出闹定 し，またイノシトール及び末知継 アルコール類 2 䡒も検 出した。

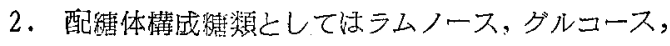


第 2 表紅茶の炭水化物組成

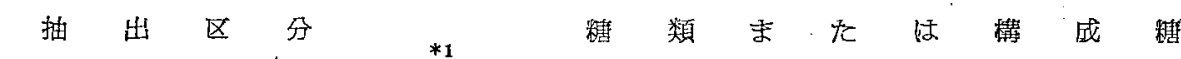

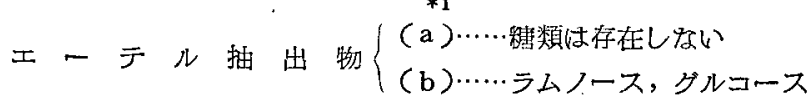

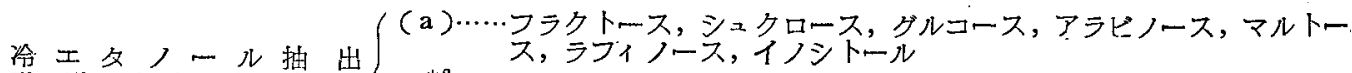

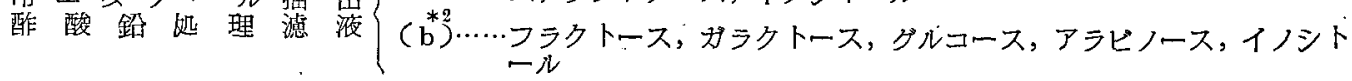

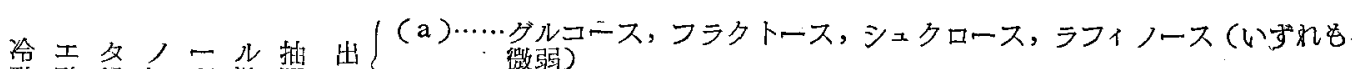

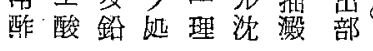

(b) …゙ラクトース, グルコース, ブラクトース。ラムノース

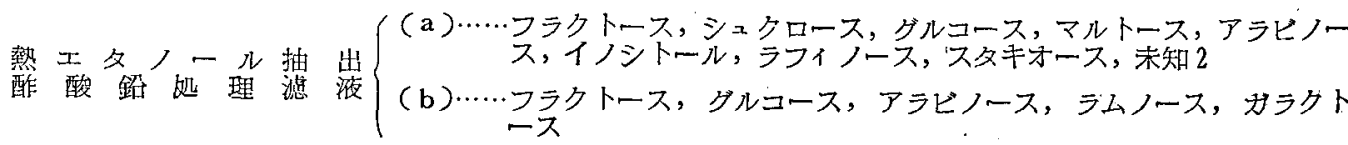

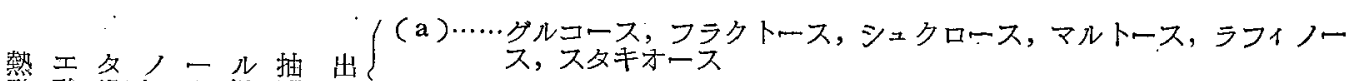

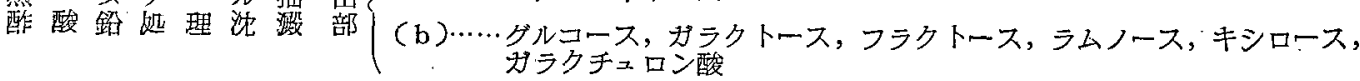

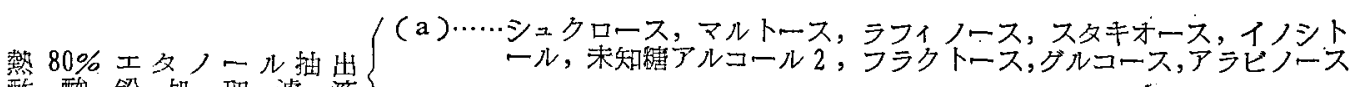

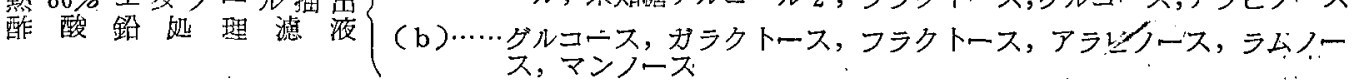

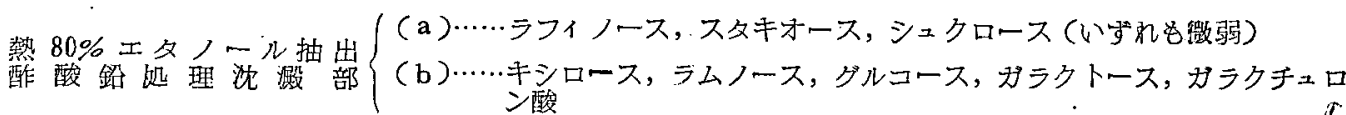

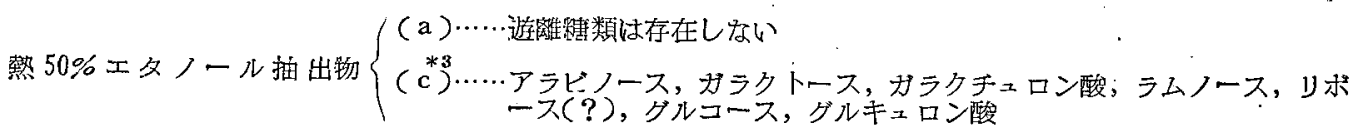

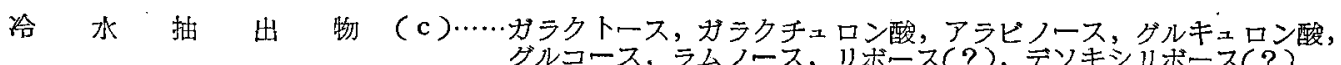

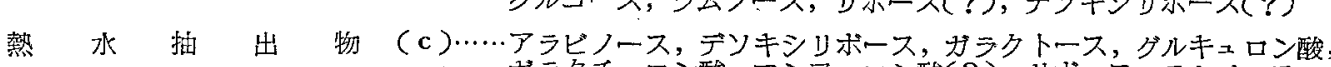

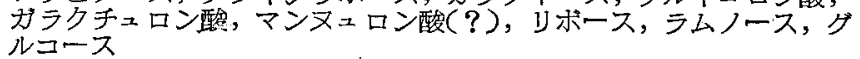

蓺 $0.5 \%$ 鉴安抽出物

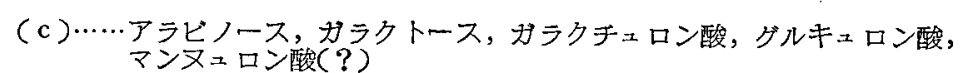
冷 $5 \%$ 苛性ソーダ抽出物 (c) ……シロース, マンノース, グルコーズ, デソキシリホース(?), リボ 蓺 $5 \%$ 䔩性ソーダ抽出物

冷 $20 \%$ 菏性ソーダ抽出 酷 酸 酸浩沈激部 冾 $20 \%$ 菏性ソー名搔出 酢 酸 酸性滤液 部 過熱 $5 \%$ 硫酸分解抽出物 冷 $70 \%$ 硫酸抽出分解物

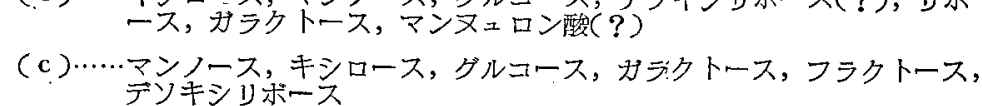

(c) ……ㅈクトース, ラムノース, テソキシリボース, キシロース, リポー

(c)․․․シロロス, ガラクトース,ラムノース

ダルコース, アラビノース

グルコース, アラビノース, キシロース

ガラクトース，フラクトース，キシロース及びガラクチ ンロン酸を柃出した。

3. 熱 $50 \%$ エタノール可溶性多䋖類の構成結類 として はアラビノース,ガラクトース，ガラクキェロン酸， ラ ムノース,グルコースを検出した。

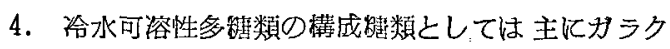
トース，ダラクチュロン酸，アラビノースを，熱水可溶

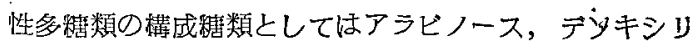
ボース，ガラクトース，グルキュロン酸，ガラクチェロ ン酸, マンヌェロン酸 (?),リボース,ラムノース,ダ

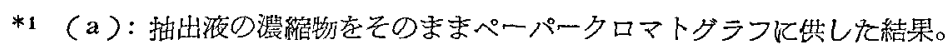

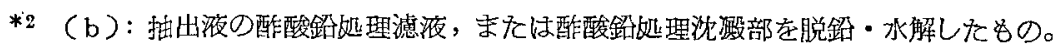

*3 (c): 抽出液を濃綃後, エタノール中へ投入し，沈澱させて得られる多艘類粉末の水解庭物。 
ルコースを検出した。

5. プロトペタチン区分の溝成糖としては アラビノー ス, カララトース, ガラクチュロン酸並びに少量のグル キュロン酸, マンヌェロン酸を唡出した。

6. ヘミセルロース構成䌅としてはキシロース，マン ノース, グルコース，リボース，テソキシリボース，ガ ラタトース及びマンヌュロン酸を， $\beta$-セルロース棈成糖 として蛙ラクト一ス, ラムノース，デソキシリボース，

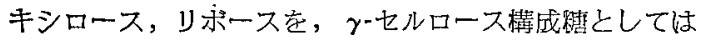
キシロース，ガラクトース，ラムノース在梌出した。

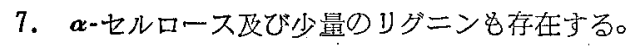

本報告の 要昌性昭和 30 年10月12日茶業枝街研究発表会 (於鹿児島市) で講演し，䛨細は日本震芝化学会誌 $[29 ，$ 847 (1955)] に発表した。

\section{6. 参考文 献}

1) 鳥井秀一, 金沢純: 農化, 28，34 (1954)；29,770 (1955).

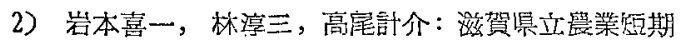
大学学術報告, 6, 30 (1954).

3) 酒戸彌二郎; 松村隆：農化，29，770 (1955).

4) Cartwright, R. A., E. A. H. Roberts: J. Sci. Food Agr., 5, 600 (1954).

5) - 水野卓, 金兵忠雄: 農化, 29, 848 (1955).

6) 水野卓, 金兵忠雄: 㖘化, 29,665 (1955).

\section{Summary}

The carbohydrates in black tea were divided into fourteen fractions. Free sugars and the component sugars of each fraction have been investigated mainly by the method of paper chromatography and the following results were obtained (see Table 2).

Fructose, glucose and arabinose were detected as free monosaccharides, and sucrose, maltose, raffino:e and stachyose as free oligosaccharides.

Inositol and two kinds of unknown substances as free sugaralchols were also detected.

Rhamnose, glucose, galactose, fructose, xylose and galacturonic acid were detected as the comp:nents of glycosides.

Arabinose, galactose, galacturonic acid, rhamose and glucose were detected as the components of hot $50 \%$ ethanol-soluble polysaccharides.

Galactose, galacturonic acid, arabinose, rhamnose, ribose (?), de:oxyribose (?) and glucuronic acid were detected as the componints of cold water-soluble polysaccharides, and besides this arabinose, galactose, galacturonic acid, desoxyribose, ribose, glucuronic acid, rhamnose and mannuronic acid as the components of hot water-soluble polysaccharides.

Arabinose, galactose, galacturonic acid and small amounts of glucuronic acid and mannuronic acid were detected as the components of hot $0.5 \%$ ammonium oxalate-soluble polysaccharides.

Xylose, mannose, glucose, ribose, desoxy ribose, galactose and mannuronic acid as the components of hemicellulose, galactose, rhamnose, desoxyribose, xylose and ribose as the $\beta$-cellulose, xylose, galactose and rhamnose as the $\gamma$-cellulose components were detected.

$\alpha$-Cellulose and a small amount of lignin were also detected.

(Mar. 10, 1956) 